\title{
A Performance and Cost Overview of Selected Solid-State Electrolytes: Race between Polymer Electrolytes and Inorganic Sulfide Electrolytes
}

\author{
Duygu Karabelli ${ }^{1, *}$, Kai Peter Birke ${ }^{1,2}$ and Max Weeber ${ }^{1}$ \\ 1 Fraunhofer Institute for Manufacturing Engineering and Automation IPA, Nobelstr. 12, 70569 Stuttgart, Germany; \\ peter.birke@ipv.uni-stuttgart.de (K.P.B.); max.weeber@ipa.fraunhofer.de (M.W.) \\ 2 Chair for Electrical Energy Storage Systems, Institute for Photovoltaics, University of Stuttgart, Pfaffenwaldring 47, \\ 70569 Stuttgart, Germany \\ * Correspondence: duygu.kaus@ipa.fraunhofer.de
}

check for updates

Citation: Karabelli, D.; Birke, K.P.; Weeber, M. A Performance and Cost Overview of Selected Solid-State Electrolytes: Race between Polymer Electrolytes and Inorganic Sulfide Electrolytes. Batteries 2021, 7, 18. https://doi.org/10.3390/ batteries7010018

Academic Editor: Carolina

Rosero-Navarro

Received: 30 January 2021

Accepted: 26 February 2021

Published: 5 March 2021

Publisher's Note: MDPI stays neutra with regard to jurisdictional claims in published maps and institutional affiliations.

Copyright: (c) 2021 by the authors. Licensee MDPI, Basel, Switzerland. This article is an open access article distributed under the terms and conditions of the Creative Commons Attribution (CC BY) license (https:// creativecommons.org/licenses/by/ $4.0 /)$.

\begin{abstract}
Electrolytes are key components in electrochemical storage systems, which provide an ion-transport mechanism between the cathode and anode of a cell. As battery technologies are in continuous development, there has been growing demand for more efficient, reliable and environmentally friendly materials. Solid-state lithium ion batteries (SSLIBs) are considered as next-generation energy storage systems and solid electrolytes (SEs) are the key components for these systems. Compared to liquid electrolytes, SEs are thermally stable (safer), less toxic and provide a more compact (lighter) battery design. However, the main issue is the ionic conductivity, especially at low temperatures. So far, there are two popular types of SEs: (1) inorganic solid electrolytes (InSEs) and (2) polymer electrolytes (PEs). Among InSEs, sulfide-based SEs are providing very high ionic conductivities (up to $10^{-2} \mathrm{~S} / \mathrm{cm}$ ) and they can easily compete with liquid electrolytes (LEs). On the other hand, they are much more expensive than LEs. PEs can be produced at less cost than InSEs but their conductivities are still not sufficient for higher performances. This paper reviews the most efficient SEs and compares them in terms of their performances and costs. The challenges associated with the current state-of-the-art electrolytes and their cost-reduction potentials are described.
\end{abstract}

Keywords: solid-state batteries; solid electrolytes; polymer electrolytes; inorganic sulfide electrolytes; lithium ion batteries; lithium metal batteries

\section{Introduction}

The first lithium batteries were already based on "Li metal" technology where metallic lithium was used as the negative electrode, achieving the highest theoretical energy densities [1]. However, the use of lithium in the metallic form coupled with an organic liquid electrolyte resulted in dendrite formation, which eventually leads to an internal short circuit and thus, a thermal runaway. The serious safety problems associated with this system stunted their growth during their years on the market. In 1991, Sony presented and marketed the first Li-ion battery (LIB) technology in which Lithium was no longer present in metallic form but only in ionic form $\left(\mathrm{Li}^{+}\right)$in a "host" material at a higher potential than lithium metal, thus limiting the formation of dendrites [2]. Since then, LIBs have been widely developed and are now present in all portable devices requiring a rechargeable battery (mobile phone, laptop, etc.). Today, the low manufacturing cost of LIBs makes them the leading technology on the market for applications in electromobility (e-mobility). However, as e-mobility (especially Electric Vehicle, EV) is an increasing market and becoming more and more attractive for millions of customers, there is a need for higher energy density cells with increased charge-discharge and thermal performances. This could be achieved through the optimization of existing LIB chemistries.

Conventional Li-ion technology is reaching its performance limits, as there can be no compromise on lifetime or safety. The latest "advanced" Li-ion systems with a silicon anode 
will not exceed energy densities of $800 \mathrm{Wh} \mathrm{L}^{-1}$ or $300 \mathrm{Wh} \mathrm{kg}^{-1}$ on a cell scale [3,4]. In order to achieve higher energy densities, it is possible to use Li metal instead of graphite as the negative electrode. Li metal has about ten-times higher specific capacity $\left(3.860 \mathrm{mAh} \mathrm{g}^{-1}\right)$ than graphite [5]. However, as stated previously, Li metal is not compatible with a liquid electrolyte system because of the formation of dendrites. Porous polymer-based separators do not provide a sufficient physical barrier to stop the breakthrough of dendrites. In addition, the existing liquid electrolytes are toxic and flammable due to the fluorinated salt $\mathrm{LiPF}_{6}$ carbonate solvents. A battery system with a liquid electrolyte can cause many safety problems in the event of accidents. Its replacement with a solid electrolyte, which is also acting as a separator, would create an inert, solid system that could solve the problems mentioned above. Solid-state batteries do not have a liquid junction, which facilitates the formation of series-connected cells in a pack. The absence of this junction eliminates unnecessary volume, resulting in higher volumetric energy densities. Hence, these new all-solid state batteries (ASSB) are currently considered as the next generation of lithium batteries.

For a successful ASSB, the solid electrolyte must meet several key criteria such as (i) high ionic conductivity, (ii) wide electrochemical stable window and chemical stability, (iii) simple management of the interfaces between the components of the cell, (iv) good mechanical properties, flexibility and (v) affordable cost [6]. There have been many studies to find the most suitable solid electrolyte to make ASSBs competitive with today's Li-ion technology.

SEs are generally classified into two main groups: inorganic electrolytes and polymer electrolytes (PE). The most commonly studied SEs are given in Figure 1.

\section{Solid Electrolytes}

\section{Inorganic Electrolytes}

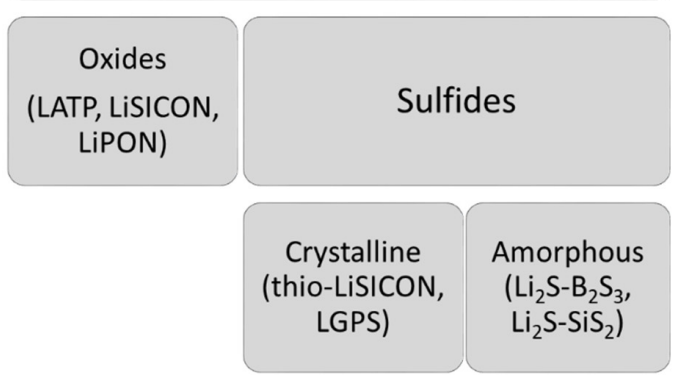

\section{Polymer Electrolytes (PE)}

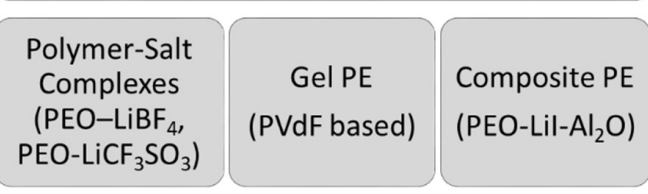

Figure 1. The most common solid electrolytes (SEs) and their examples $[7,8]$.

Under inorganic electrolytes, Lithium SuperIonic CONductor (LiSICON) andderivatives are widely used as oxide-type electrolytes due to their lower reactivity with water and air. However, they show lower ionic conductivity at room temperature (RT) $\left(\sim 10^{-7} \mathrm{~S} \mathrm{~cm}^{-1}\right)$ compared to sulfide electrolytes [9]. In 1989, Aono et al. showed that Sodium (Na) SuperIonic CONductor (NaSICON)-type electrolytes such as $\mathrm{Li}_{1+x} \mathrm{Al}_{\mathrm{x}} \mathrm{Ti}_{2-\mathrm{x}}(\mathrm{PO} 4)_{3}$ (LATP) offer an ionic conductivity of $7 \times 10^{-4} \mathrm{~S} \mathrm{~cm}^{-1}$ and a wide electrochemical window of $6 \mathrm{~V}$ [10]. In recent years, LATP electrolytes have been often discussed and even started to be produced by some companies [8]. An often neglected, underestimated and maybe entirely unknown fact of SEs is their lithium activity and the related stability window. Usually, solid Li-Ion conductors are still considered as inert. However, Li-Ions are partially highly mobile. Some types of Li-Ion conductors (e.g., garnet LLZO) seem to show a kinetic stability with metallic lithium. However, their reactions with $\mathrm{H}_{2} \mathrm{O}$ and $\mathrm{CO}_{2}$ have been 
extensively reported, e.g., in [11]. This reveals a high tendency to release lithium rather than to accept or to insert it. LLZO acts, in contrary to LATP, much more as a Li-donor than a Li-acceptor.

Consequently, one has to attribute a lithium activity that is at least high enough to promote reaction with water and carbon dioxide. Therefore, it is opportune to speak about high lithium activities in such compounds. Generally, it seems to be a crucial dilemma that lithium activities, with $\mathrm{H}_{2} \mathrm{O}$ and $\mathrm{CO}_{2}$, are a necessary evil to provide at least the kinetic stability of $\mathrm{H} 20$ and $\mathrm{CO} 2$ with lithium metal. However, solid Li-ion conductors, which have a comparable sensitivity, tend to readily absorb lithium. The only way to solve this dilemma is to hypothetically block such reactions using extremely high electronic resistances. This delays the movement of electrons to allow sufficient time for the reactions to occur. However, this is impossible in reality for solid Li-Ion conductors, which always show inherent stoichiometric deviations as a consequence of preparation routes. They are not perfect crystals but powders and even perfect crystals have surfaces with different effects to those of the bulk. This is a tremendously important issue to be investigated and to be discussed for oxide-based electrolytes such as those with garnet structure, e.g., LLZO [12].

Lithium phosphorous oxy-nitride "LiPON" electrolytes are another type of inorganic oxide electrolytes with ionic conductivity of $\sim 2 \times 10^{-6} \mathrm{~S} \mathrm{~cm}^{-1}$, which is somewhere in between LATP and LiSICON conductivity [8].

The other subcategory of inorganic electrolytes, the sulfide family generally has higher conductivities (up to $2.5 \times 10^{-2} \mathrm{~S} \mathrm{~cm}^{-1}$ ) than the oxides due to the higher polarizability and larger size of sulfur compared to oxygen [7]. Crystalline (glass-ceramic) sulfide electrolytes (thio-LiSICON family) are represented with the general formula $\mathrm{Li}_{\mathrm{x}} \mathrm{M}_{1-\delta} \mathrm{M}_{\delta}{ }^{\prime} \mathrm{S}_{4}$, where $\mathrm{M}$ represents $\mathrm{Si}, \mathrm{Ge}, \mathrm{Sn}$ and $\mathrm{M}^{\prime}$ represents $\mathrm{P}, \mathrm{Ga}, \mathrm{Al}$ and $\mathrm{Zn}$ [13]. Within this family, the crystalline sulfide electrolytes $\mathrm{Li}_{10} \mathrm{GeP}_{2} \mathrm{~S}_{12}$ (LGPS) and argyrodite-type crystallines $\mathrm{Li}_{6} \mathrm{PS}_{5} \mathrm{X}(\mathrm{X}=\mathrm{Cl}, \mathrm{Br}, \mathrm{I})$ (LPS) are the most popular ones with their ionic conductivity of $1.9 \times 10^{-3} \mathrm{~S} \mathrm{~cm}^{-1}$ and $6.8 \times 10^{-3} \mathrm{~S} \mathrm{~cm}^{-1}, \mathrm{X}=\mathrm{Cl}$ and $\mathrm{Br}$, respectively [9,14].

Amorphous (glassy)-type sulfide electrolytes are ductile and they require very high temperatures for a cell assembly to avoid the crystallization of the sulfide glasses [15].

As mentioned, SEs should have good mechanical properties, especially moderate elasticity (Young's modulus), since they need to adjust their form with the volume change of electrodes during charging and discharging [16]. However, having a low Young's modulus $\left(E^{\prime}\right)$ is also not enough. The material must show good strength at the same time in order to resist dendrite formation. It has been reported that, for a dendrite-free deposition, the shear modulus $\left(G^{\prime}\right)$ of an SE should be at least twice that of lithium metal $\left(G^{\mathrm{Li}}=3.4 \mathrm{GPa}\right)[17,18]$.

Polymer electrolytes (PEs) have many particularly interesting characteristics. They are flexible $\left(\mathrm{E}_{\mathrm{PEO}}^{\prime}=70 \mathrm{MPa}\right)[18]$, light, and their thickness can be controlled in the order of ten micrometers by different preparation techniques such as extrusion or pressing. The most studied PE for all-solid batteries is polyethylene oxide (PEO) coupled with a lithium salt [19]. Their conductivities lie around $10^{-4} \mathrm{~S} \mathrm{~cm}^{-1}$ depending on the lithium salt used [8]. Gel PEs are prepared with a low crystalline polymer such as poly(vinylidene fluoride)-co-hexafluoropropylene (PVdF-HFP) and an organic liquid electrolyte such as LiPF6 in EC-DMC) in the polymer matrix. Despite their good ionic conductivities (up to $\left.6 \times 10^{-3} \mathrm{~S} \mathrm{~cm}^{-1}\right)$ [8], they suffer from lower mechanical strength $\left(\mathrm{G}^{\mathrm{PEO}}=26.2 \mathrm{MPa}\right)$ and electrode compatibilities [19].

As it can be seen, each family of SEs has its advantages and disadvantages, and each of them should be considered depending on the ASSB applications. Typically, organic liquid electrolytes for commercialized Li-Ion batteries show conductivities of about $2 \times 10^{-2} \mathrm{~S} \mathrm{~cm}^{-1}$ at room temperature. Assuming a porosity of typical polyolefin separators of about $40 \%$ [20], a resulting conductivity of about $5 \times 10^{-3} \mathrm{~S} \mathrm{~cm}^{-1}$ remains as a rule of thumb. SEs have to compete at least with these values, also taking into account that typical polyolefin separators have thicknesses in the range of 20-25 $\mu \mathrm{m}$ [20], which are difficult to realize with Li metal solid-state ion conductions in practice. This is a strong reason for looking at sulfide-based solid electrolytes rather than oxide-based ones since 
the latter do usually not exceed $5 \times 10^{-4} \mathrm{~S} \mathrm{~cm}^{-1}$ even in the bulk phase. Besides, oxidebased solid Li-Ion conductors are not the focus of the present paper since sulfide- and/or phosphide-based candidates are much more promising to successfully bridge the gap to their liquid competitors. Solid polymer electrolytes (SPEs) will also be discussed due to their higher stability against Li metal anode.

\section{Solid Electrolytes}

\subsection{Inorganic Sulfide Electrolytes}

The Thio-LISICON family, a sulfur derivative of LISICON, was initially introduced by Kanno et al. [21]. They have replaced $\mathrm{O}^{2-}$ ions with $\mathrm{S}^{2-}$ ions, which increased the mobility of $\mathrm{Li}^{+}$ions due to their larger size and more polarizable character. It has been shown that this substitution allows for an increase in the ion conductivity by two orders of magnitude (e.g., $2 \times 10^{-6} \mathrm{~S} \mathrm{~cm}^{-1}$ for a $\mathrm{Li}_{3.6} \mathrm{Si}_{0.6} \mathrm{P}_{0.4} \mathrm{O}_{4}$ and $10^{-4} \mathrm{~S} \mathrm{~cm}^{-1}$ for $\mathrm{Li}_{2} \mathrm{~S}-\mathrm{SiS}_{2}$-LiI) [21].

In recent years, one electrolyte and its derivatives have increasingly emerged as the first suitable candidate. This is, for example, LGPS with the empirical formula $\mathrm{Li}_{10} \mathrm{GeP}_{2} \mathrm{~S}_{12}$. Here, even conductivities in the particle of more than $10^{-2} \mathrm{~S} \mathrm{~cm}^{-1}$ are reported [21,22]; a practical achievement was $\sim 10^{-3} \mathrm{~S} \mathrm{~cm}^{-1}$ in a suitably prepared whole electrode $[23,24]$. It is expected that a powder of this electrolyte can be compacted into films with an inert auxiliary binder so that satisfactory contact of the individual crystals with a sufficient density can be achieved in order to suppress dendrites.

Moreover, research results indicate that $\mathrm{Li}_{10} \mathrm{GeP}_{2} \mathrm{~S}_{12}$ is compatible with NMC (8:1:1) cathodes, $\mathrm{LiNi}_{0.8} \mathrm{Co}_{0.1} \mathrm{Mn}_{0.1} \mathrm{O}_{2}$, which is considered an up-and-coming candidate for $\mathrm{Li}$-ion cells. Such a cathode would then contain the solid electrolyte in the gaps of the densest NMC sphere (cubic close pack), for example, about 10-25 $\mu \mathrm{m}$ thick NCM cathode particles. The solid electrolyte must have particle sizes of at least one order of magnitude less for this to occur, an important design feature for the solid electrolyte powder. Thus, particles in the nanometer range are required.

However, there are still some challenges concerning their stability with the electrode interface and affordability. Regarding the electrochemical stability of LGPS, it is relatively limited due to the reduction of $\mathrm{Ge}^{4+}$ in $\mathrm{Ge}^{0}$ below $1.0 \mathrm{~V} \mathrm{vs}$. $\mathrm{Li}$, and the oxidation of $\mathrm{S}^{2-}$ above $2.8 \mathrm{~V}$ vs. Li. Its strong reactivity at the interface with the Li metal forms products, which lead to the decomposition of LGPS, producing undesirable interphase products composed of $\mathrm{Li}_{3} \mathrm{P}, \mathrm{Li}_{2} \mathrm{~S}$, and Li-Ge alloy [25]. Actually, the decomposition products $\mathrm{Li}_{3} \mathrm{P}$ and $\mathrm{Li}_{2} \mathrm{~S}$ are expected to be sufficiently good solid ionic conductors to enable ionic conductivity, but $\mathrm{Li}_{\mathrm{x}} \mathrm{Ge}$ alloy causes unfavorable repeated volume surges during the formation and delithiation of the alloy. That is why the stability to so-called 4 and even $5 \mathrm{~V}$ electrodes of sulfidic compounds needs further study.

In order to overcome these stability issues, several surface modification methods have been proposed $[15,24,25]$. For example, Zhang et al. proposed the use of a protective layer between LGPS SE and the $\mathrm{Li}$ metal anode, namely $\mathrm{LiH}_{2} \mathrm{PO}_{4}$ [24]. They have coated the $\mathrm{Li}$ metal with different concentrations of $\mathrm{H}_{3} \mathrm{PO}_{4}$ tetrahydrofuran and created an in-situ $\mathrm{LiH}_{2} \mathrm{PO}_{4}$ surface. In this way, they achieved $113.7 \mathrm{mAh} \mathrm{g}^{-1}$ of a discharge capacity up to 500 cycles (at $0.1 \mathrm{C}$ with $80 \mathrm{wt} \% \mathrm{H}_{3} \mathrm{PO}_{4}$ ). Nevertheless, the surface treatments increased the total impedance of the Li anode (more than 2.5 times). Additionally, it has been reported that long-term cycling causes a volume changing effect.

Another proposition to increase the stability of the LGPS solid electrolyte towards the Li metal anode is to prepare the cells with double-layer (bilayer) electrolytes [26-30]. Within this approach, a Li-compatible SE-layer (mostly based on $\mathrm{Li}_{2} \mathrm{~S}_{-} \mathrm{P}_{2} \mathrm{~S}_{5}$ ) is inserted between LGPS and Li metal. The cell characteristics prepared with bilayer electrolytes are summarized in Table 1.

As can be seen in Table 1, the cells prepared with the bilayer InSEs showed better cycle and capacity performance compared to that of single-layer LGPS electrolyte. Relatively higher cycle numbers for the electrolytes prepared with $\mathrm{Li}_{2} \mathrm{~S}-\mathrm{P}_{2} \mathrm{~S}_{5}$ and $\mathrm{Li}_{9.6} \mathrm{P}_{3} \mathrm{~S}_{12}$ can be attributed to their dendrite-resistant glass-ceramic structures (higher Shear Modulus). In 
case of electrolytes prepared with $\mathrm{Li}_{2} \mathrm{~S}_{-} \mathrm{P}_{2} \mathrm{O}_{5}$, the cycle number is significantly higher than that of any other cells. Many studies reported that electrolytes with oxygen atoms in their structure showed remarkable cycle stability because oxygen ions are able to suppress the side reactions between sulfide electrolyte and lithium metal [27,28].

Table 1. Electrochemical properties of $\mathrm{Li}_{10} \mathrm{GeP}_{2} \mathrm{~S}_{12}$ (LGPS) mono and bilayer solid electrolytes with various cell types.

\begin{tabular}{|c|c|c|c|c|c|}
\hline Solid Inorganic Electrolyte & Cathode & $\begin{array}{l}\text { Energy Density } \\
\quad\left(\mathrm{Wh} \mathrm{kg}^{-1}\right)\end{array}$ & $\begin{array}{l}\text { Full Cell Capacity } \\
\quad\left(m A h \mathrm{~g}^{-1}\right)\end{array}$ & Cycle & Reference \\
\hline $\mathrm{Li}_{10} \mathrm{GeP}_{2} \mathrm{~S}_{12}$ & $\mathrm{LCO}_{-} \mathrm{LiNbO}_{3}$ & - & 114 (at $0.12 \mathrm{C}$ ) & 8 & [22] \\
\hline $\mathrm{Li}_{10} \mathrm{GeP}_{2} \mathrm{~S}_{12} / / \mathrm{Li}_{9.6} \mathrm{P}_{3} \mathrm{~S}_{12}$ & $\mathrm{LCO}-\mathrm{LiNbO}_{3}$ & 33 & 114 (at $0.12 \mathrm{C}$ ) & 30 & [30] \\
\hline $\mathrm{Li}_{10} \mathrm{GeP}_{2} \mathrm{~S}_{12} / / \mathrm{Li}_{2} \mathrm{~S}-\mathrm{P}_{2} \mathrm{~S}_{5}$ & NiS-CNT & - & 170 & 150 & [29] \\
\hline $\mathrm{Li}_{10} \mathrm{GeP}_{2} \mathrm{~S}_{12} / / \mathrm{Li}_{2} \mathrm{~S}-\mathrm{P}_{2} \mathrm{O}_{5}$ & $\mathrm{LCO}-\mathrm{Li}_{7} \mathrm{P}_{3} \mathrm{~S}_{11}$ & 17 & 647 (at $0.06 C$ ) & 1000 & [28] \\
\hline $\mathrm{Li}_{10} \mathrm{GeP}_{2} \mathrm{~S}_{12} / / \mathrm{Li}_{3} \mathrm{P}_{0.98} \mathrm{Sb}_{0.02} \mathrm{~S}_{3.95} \mathrm{O}_{0.05}$ & LCO-LiNbO 3 & 14 & 134 (at $0.09 \mathrm{C}$ ) & 50 & [27] \\
\hline $\mathrm{Li}_{3.15} \mathrm{Ge}_{0.15} \mathrm{P}_{0.85} \mathrm{~S}_{4} / / \mathrm{Li}_{2} \mathrm{~S}_{-} \mathrm{P}_{2} \mathrm{~S}_{5}$ & $\mathrm{LCO}-\mathrm{Al}_{2} \mathrm{O}_{3}$ & 7 & 121 (at $0.13 \mathrm{C}$ ) & 25 & [26] \\
\hline
\end{tabular}

Another decisive factor for the commercialization of LGPS electrolytes is their price. $\mathrm{Li}_{2} \mathrm{~S}, \mathrm{P}_{2} \mathrm{~S}_{5}, \mathrm{GeS}_{2}$ are the starting materials and the synthesis of LGPS solid electrolyte takes place between 500 and $600{ }^{\circ} \mathrm{C}$ in an inert atmosphere [31]. As germanium is an expensive element (1300 US \$ $/ \mathrm{kg}$ ) [32], the substitution of the critical element Ge has been achieved by isovalent elements such as $\mathrm{Si}$ or $\mathrm{Sn}$ (starting materials $\mathrm{SiS}_{2}$ and $\mathrm{SnS}_{2}$ ), which are much more affordable while only moderately affecting only moderately the conductivity performances [33]. A detailed price analysis is provided in Section 3.

As mentioned in the introduction, another interesting sulfide electrolyte is based on argyrodite-type compounds $\mathrm{Li}_{6} \mathrm{PS}_{5} \mathrm{X}(\mathrm{X}=\mathrm{Cl}, \mathrm{Br}, \mathrm{I})$, shortly named as LPS-X solid electrolyte. Their preparation generally includes mechanical milling followed by heating at $500-600{ }^{\circ} \mathrm{C}$ in order to obtain the argyrodite phase. The starting materials are $\mathrm{Li}_{2} \mathrm{~S}, \mathrm{P}_{2} \mathrm{~S}_{5}$, and $\mathrm{LiX}$ [34]. Deiseroth et al. presented a detailed study on the synthesis of different LPS-X electrolytes and examined their crystal structures [34]. The highest Li-ion mobility was observed for $\mathrm{Li}_{6} \mathrm{PS}_{5} \mathrm{Br}$ electrolyte [14,34]. On the other hand, the compounds prepared with LiI showed a conductivity of only $4.6 \times 10^{-7} \mathrm{~S} \mathrm{~cm}^{-1}$ [14]. Even though $\mathrm{Li}_{6} \mathrm{PS}_{5} \mathrm{I}$ has an almost identical lattice structure compared to its relatives, it has not been clearly understood so far where the difference in the ionic conductivity values comes from. Recently, Hanghofer et al. studied substitutional disorder effects of LPS-X electrolytes by broadband impedance spectroscopy and ${ }^{7} \mathrm{Li}$ NMR relaxation measurements [35]. They found that the anion disorder in LPS-Cl and LPS-Br supports faster Li-ion transport. Nazar et al. also showed that the same kind of phenomena can be observed in mixed halide argyrodites LPS- $X\left(X=\mathrm{Cl}_{0.75} \mathrm{Br}_{0.25}, \mathrm{Cl}_{0.5} \mathrm{Br}_{0.5}\right.$, and $\mathrm{Cl}_{0.25} \mathrm{Br}_{0.75}$ ) [36]. For example, the electrolytes containing $\mathrm{Cl}_{0.75} \mathrm{Br}_{0.25}$ and $\mathrm{Cl}_{0.5} \mathrm{Br}_{0 . .5}$ showed an ionic conductivity of $3.2 \times 10^{-3}$ and $3.9 \times 10^{-3} \mathrm{~S} \mathrm{~cm}^{-1}$, respectively, where this value was obtained as $3.4 \times 10^{3} \mathrm{~S} \mathrm{~cm}^{-1}$ for an electrolyte containing $\mathrm{Cl}_{0.25} \mathrm{Br}_{0.75}$. This behavior was explained by the low concentrations of $\mathrm{Br}$, which resulted in more conductive pathways in the material structure. In contrast, excessive concentrations effectively blocked these channels and reduced the degree of percolation and ionic conductivity. Another study, which was performed by Viallet et. al, also showed that the conductivity of LPS-Cl electrolyte can be increased by optimization of the milling time [37]. They increased the ionic conductivity value from $2 \times 10^{-4} \mathrm{~S} \mathrm{~cm}^{-1}$ to $1.33 \times 10^{-3} \mathrm{~S} \mathrm{~cm}^{-1}$ by increasing the milling time from 1 to $10 \mathrm{~h}$.

The cells prepared with a LGPS solid electrolyte show the same dendrite problems as cells prepared with argyrodite-type electrolytes. Although the LPS-Cl compound shows good stability to the phenomenon of lithium dissolution and deposition, it has been shown that contact losses at the interface with lithium occur when high currents are applied. High currents result in the formation of dendrites and the appearance of other degradation products ( $\mathrm{Li}_{2} \mathrm{~S}, \mathrm{P}_{2} \mathrm{~S}_{\mathrm{x}}$ and polysulfides) [38,39]. One of the solutions to overcome this problem is the use of $\mathrm{LiCoO}_{2} / \mathrm{L}_{4} \mathrm{Ti}_{5} \mathrm{O}_{12}$ cells [40]. Nevertheless, a breakthrough 
battery design has been presented by researchers from the Samsung Advanced Institute of Technology (SAIT) and the Samsung R\&D Institute Japan (SRJ) [41]. They used a silvercarbon $(\mathrm{Ag}-\mathrm{C})$ composite layer at the anode, and there was no need to handle the Li metal sheet during the cell assembly process. The cathode acted as the sole source of the lithium and while charging, Li metal deposited on the stainless steel current collector. These cells showed an energy density greater than $900 \mathrm{Wh}^{-1}$ and long cycle life (1000 times). However, taking into account that silver is an expensive element and the change of Agdistribution in the $\mathrm{Ag}-\mathrm{C}$ nanocomposite layer (after 100 cycles) make the commercialization of this cell difficult. The cost/performance ratio continues to remain a challenge.

\subsection{Solid Polymer Electrolytes}

As the solid polymer electrolytes (SPEs) have a softer nature compared to the InSEs, they have more flexibility, and as a result, they offer better processability [42]. Moreover, this flexibility allows them to respond to volume changes within the cell due to lithiation. Cheng et al. reported that for the $\mathrm{LiFePO}_{4}$ (LFP) cathode, the volume change is about $6.6 \%$ [43], and as the SE is directly neighboring the cathode, its flexible nature prevents the electrolyte from irreversible deformations.

The most studied polymer as a SPE is polyethylene oxide (PEO) coupled with the lithium salt, LiTFSI [44-53]. However, sole PEO-based electrolytes exhibit relatively low ionic conductivity (ca. $10^{-7}-10^{-5} \mathrm{~S} \mathrm{~cm}^{-1}$ ) at room temperature. In order to increase their ionic conductivity, they are prepared as composite electrolytes [54-59]. Composite SPEs contain PEO in their composition because PEO-based electrolytes are relatively more stable against Li metal and PEO can dissolve the conductive lithium salt easier due to its polar ether groups.

PEO-based composite SPEs are mainly used with a low-voltage LFP cathode [51-56] because PEO shows low stability at potentials greater than $3.8 \mathrm{~V}$ (vs. $\mathrm{Li}+/ \mathrm{Li}$ ) and an oxidative decomposition occurs $[60,61]$. This limitation prevents it from using the most popular cathode materials, such as NCA or NMC, which require potentials up to 4.1-4.2 V. Nevertheless, Wakayama et al. have proposed a three-dimensional structure and built cells with $\mathrm{LiCoO}_{2}$ (LCO) composed of $\mathrm{Li}_{7} \mathrm{La}_{3} \mathrm{Zr}_{2} \mathrm{O}_{12}$ (LLZ) [57]. Their cells were suitable for cycling between 3.0 and $4.2 \mathrm{~V}$ (up to 20 cycles). Table 2 summarizes some results of ASSB cell results obtained with PEO-based composite electrolytes and a Li metal anode.

Table 2. Cell characteristics of all-solid state batteries (ASSB) cells prepared with composite polyethylene oxide (PEO) solid electrolyte.

\begin{tabular}{|c|c|c|c|c|c|}
\hline Solid Polymer Electrolyte & Cathode & $\begin{array}{l}\text { Energy Density } \\
\quad\left(\mathrm{Wh} \mathrm{kg}^{-1}\right)\end{array}$ & $\begin{array}{l}\text { Full Cell Capacity } \\
\quad\left(m A h \mathrm{~g}^{-1}\right)\end{array}$ & Cycle & Ref. \\
\hline $\mathrm{Ca}-\mathrm{CeO}_{2} / \mathrm{LiTFSI} / \mathrm{PEO}$ & LFP & - & 157 (at $0.2 C$ ) & 40 & [54] \\
\hline 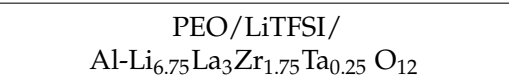 & LFP- $\mathrm{In}_{2} \mathrm{O}_{5} \mathrm{Sn}$ & $334\left(\mathrm{Wh} \mathrm{l}^{-1}\right)$ & 155 (at $0.01 C$ ) & 10 & [55] \\
\hline poly(-LiMTFSI)-b-PEO-b-poly(LiMTFSI) & LFP & 168 & 158 (at $0.1 C$ ) & 300 & [56] \\
\hline PEO-LiTFSI & $\mathrm{LCO}-\mathrm{Li}_{7} \mathrm{La}_{3} \mathrm{Zr}_{2} \mathrm{O}_{12}$ & 141 & 136 (at $0.05 C$ ) & 20 & [57] \\
\hline poly(LiTFSI)-b-PEO-b-poly(LiTFSI) & LFP & 282 & 158 (at $0.36 \mathrm{C}$ ) & 1400 & [58] \\
\hline poly(STFSILi)-b-PEO-b-poly(STFSILi) & LFP & 120 & 162 (at $0.07 C$ ) & - & [59] \\
\hline
\end{tabular}

In order to prepare a good conductive $\mathrm{SPE}$, inorganic materials are introduced into the PEO matrix. Some oxides such as $\mathrm{Al}_{2} \mathrm{O}_{3}, \mathrm{TiO}_{2}, \mathrm{ZnAl}_{2} \mathrm{O}_{4}, \mathrm{CeO}$, and $\mathrm{SiO}_{2}$ in the PEO matrix increase not only the ionic conductivity values but also the electrochemical stability and the mechanical strength [54]. Among them, $\mathrm{PEO}$ in combination with $\mathrm{Al}_{2} \mathrm{O}_{3}$ and $\mathrm{SiO}_{2}$ particles is considered the most promising electrolyte [55].

The addition of lithium garnet (i.e., $\mathrm{Li}_{6.75} \mathrm{La}_{3} \mathrm{Zr}_{1.75} \mathrm{Ta}_{0.25} \mathrm{O}_{12}$, LLZTO) to the PEO matrix also results in higher conductivity values. Moreover, due to their stability at higher potentials, it is possible to use them with high-voltage cathodes [62]. Zhang et al. presented 
a study by preparing a PEO-based composite SPE without using a Li salt [62]. They have reported that the addition of nanosize LLZTO particles (with $\mathrm{D}_{50}=43 \mathrm{~nm}$ ) shifted the oxidation potential of PEO from 4.0 to $5.0 \mathrm{~V}$. This behavior can be attributed to the fact that solid-state inorganic polymer ion-conducting composites, such as LLZO-PEO often show extended stability windows. However, chemical reactions are not defined electronic switches such as "on" and "off". Thus, more precisely, the visible onset of a chemical decomposition reaction as a function of the voltage is shifted. The reason can simply be seen in the effective reactive surface. By its nature, nano-scaled LLZO yields a very high surface with a strong additional tendency to produce $\mathrm{LiOH}$ and $\mathrm{Li}_{2} \mathrm{CO}_{3}$, which are quite stable compounds. These likely cover, as LLZTO nanopowder, huge parts of the PEO and produce a shielding and coating effect, which may mislead someone into believing PEO has become more stable.

The same study also showed that dendrites coming from the Li anode were suppressed. No dendrite formation was observed after more than $700 \mathrm{~h}$ of cycling since the accumulation of lithium was hindered in the insulating polymer matrix. The cells containing the same composite membranes but prepared with conducting LiTFSI salt showed the dendrite formation after $25 \mathrm{~h}$ of cycling. The LiTFSI-free SPE also showed a high ionic conductivity $\left(2.1 \times 10^{-4} \mathrm{~S} \mathrm{~cm}^{-1}\right)$ at $30^{\circ} \mathrm{C}$.

As shown in Table 2, LFP cathode can also be prepared with indium tin oxide $\left(\mathrm{In}_{2} \mathrm{O}_{5} \mathrm{Sn}\right)$ to increase the cell's electronic conductivity by increasing the surface quality between the electrode and SPE.

\section{Choosing the Best Electrolyte: Commercialization and Mass Production Challenges}

The next generations of batteries should meet very high expectations in terms of driving range, environmental impact, charging speed, and cost. The electrolyte plays a vital role in the composition of batteries since the characteristics of the electrolyte, and in particular its electrochemical stability window, determine the electrode materials that can be used. The properties of the electrolyte dictate the operating temperature range and ultimately define the performance of the battery.

Solid polymer electrolytes are already used and commercialized in all-solid systems (Lithium Metal Polymer) for EVs. However, their low ionic conductivity requires the battery to be operated between 60 and $80^{\circ} \mathrm{C}$. In 2011, the Bolloré group (Blue Solutions) commercialized an EV (Bluecar) running with a solid-state battery [63-65] within the project frame of Autolib based on the work of Hovington et al. [58]. This SSB consisted of a Li metal anode, LFP cathode, and PEO/LiTFSI SE. This battery pack delivered an energy density of $100 \mathrm{Wh} \mathrm{kg}^{-1}$ at pack level and could run more than 1000 cycles [66]. However, their high operation temperature $\left(\sim 80^{\circ} \mathrm{C}\right)$ due to the low ionic conductivity at room temperature still hinder their broader application.

In the category of inorganic electrolytes, the thio-LISICON sulfide family shows promising ionic conductivity at lower temperatures. Another advantage is that they can be processed at room temperature. The conductivities of different solid-state electrolytes are given in Table 3.

Table 3. Ionic conductivities and costs of different types of solid electrolytes (For the solid polymer electrolytes (SPEs), only the cost of starting raw materials is given since they are not commercialized yet. The prices for inorganic solid electrolytes are received from different suppliers, and the average values are given).

\begin{tabular}{|c|c|c|c|c|c|c|}
\hline Solid Electrolyte (SE) & $\begin{array}{l}\text { Conductivity } \\
\left(\mathrm{S} \mathrm{cm}^{-1}\right)\end{array}$ & $\begin{array}{l}\text { Cost of SE from } \\
\text { Producers (\$/10 g) }\end{array}$ & \multicolumn{2}{|c|}{$\begin{array}{c}\text { Cost of Raw Materials } \\
(\$)\end{array}$} & $\underset{(g)}{\text { Amount }}$ & Ref. \\
\hline $\mathrm{Ca}-\mathrm{CeO}_{2} / \mathrm{LiTFSI} / \mathrm{PEO}$ & $1.3 \times 10^{-4}\left(60^{\circ} \mathrm{C}\right)$ & Not commercial & $\begin{array}{c}\mathrm{Ce}\left(\mathrm{NO}_{3}\right)_{3} 6 \mathrm{H}_{2} \mathrm{O} \\
\mathrm{Ca}\left(\mathrm{NO}_{3}\right)_{2} \cdot 4 \mathrm{H}_{2} \mathrm{O} \\
\text { PVP } \\
\text { LiTFSI } \\
\text { PEO }\end{array}$ & $\begin{array}{c}356 \\
15 \\
54 \\
198 \\
70\end{array}$ & $\begin{array}{l}100 \\
500 \\
100 \\
100 \\
100\end{array}$ & [54] \\
\hline
\end{tabular}


Table 3. Cont.

\begin{tabular}{|c|c|c|c|c|c|c|}
\hline Solid Electrolyte (SE) & $\begin{array}{l}\text { Conductivity } \\
\qquad\left(\mathrm{S} \mathrm{cm}^{-1}\right)\end{array}$ & $\begin{array}{l}\text { Cost of SE from } \\
\text { Producers }(\$ / 10 \mathrm{~g})\end{array}$ & \multicolumn{2}{|c|}{$\begin{array}{c}\text { Cost of Raw Materials } \\
\text { (\$) }\end{array}$} & $\underset{(\mathrm{g})}{\text { Amount }}$ & Ref. \\
\hline 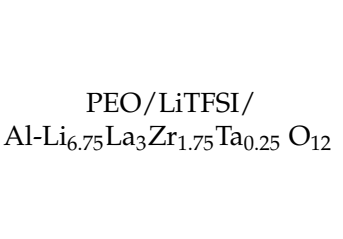 & $2.4 \times 10^{-4}\left(30^{\circ} \mathrm{C}\right)$ & Not commercial & $\begin{array}{c}\mathrm{LiOH} \cdot \mathrm{H}_{2} \mathrm{O} \\
\mathrm{La}_{2} \mathrm{O}_{3} \\
\mathrm{ZrO}_{2} \\
\mathrm{Ta}_{2} \mathrm{O}_{5} \\
\mathrm{Al}_{2} \mathrm{O}_{3} \\
\mathrm{LiTFSI} \\
\mathrm{PEO}\end{array}$ & $\begin{array}{c}150 \\
75 \\
45 \\
260 \\
30 \\
198 \\
70\end{array}$ & $\begin{array}{c}25 \\
100 \\
100 \\
50 \\
100 \\
100 \\
100\end{array}$ & {$[55]$} \\
\hline $\mathrm{Li}_{10} \mathrm{GeP}_{2} \mathrm{~S}_{12}$ & $1.2 \times 10^{-2}($ at RT $)$ & 695 & $\begin{array}{l}\mathrm{L}_{2} \mathrm{~S} \\
\mathrm{P}_{2} \mathrm{~S}_{5} \\
\mathrm{GeS} 2\end{array}$ & $\begin{array}{c}670 \\
34 \\
500\end{array}$ & $\begin{array}{c}50 \\
100 \\
1\end{array}$ & {$[67]$} \\
\hline $\mathrm{Li}_{6} \mathrm{PS}_{5} \mathrm{Cl}$ & $10^{-4}($ at RT) & 360 & $\begin{array}{l}\mathrm{L}_{2} \mathrm{~S} \\
\mathrm{P}_{2} \mathrm{~S}_{5} \\
\mathrm{LiCl}\end{array}$ & $\begin{array}{c}670 \\
34 \\
70\end{array}$ & $\begin{array}{c}50 \\
100 \\
100\end{array}$ & {$[7]$} \\
\hline Liquid electrolyte & $10^{-2}$ (at RT) & $\$ 12 / \mathrm{kg}$ & & & & [68] \\
\hline
\end{tabular}

Although InSEs show excellent ionic conductivities and can compete with organic liquid electrolytes, they are much more expensive compared to SPEs. Currently, their high cost prevents ASSBs from being a viable option for cost-effective manufacturing. It must be noted that the prices for sulfide-based electrolytes decrease if significant production capacities are set up in the future. However, in the case of $\mathrm{Li}_{10} \mathrm{GeP}_{2} \mathrm{~S}_{12}$ (LGPS), the high cost of germanium still hinders the possibility of its large-scale production $[69,70]$.

Additionally, the stability of SEs with Li metal is one of the main factors for any production or commercialization. Sulfide-based solid electrolytes may form $\mathrm{H}_{2} \mathrm{~S}$ in contact with water, which is a gas that is then released and precludes insulating compounds from forming on the solid electrolyte surfaces during production [69-71]. Though this seems only a question of production water traces and "impure" air, it is crucial to get reproducible results and match costs. Vice versa, following this argument, it can be a consequent outcome that, e.g., LLZO is a dead walk for any production and commercialization. For this reason, this paper does not discuss oxide-based solid electrolytes.

The other key point to bring ASSBs to the market is to develop scalable manufacturing technologies [72]. The current LIB manufacturing lines are not easy to leave behind and start over. New investments, given current technological advances, would cost much more than those required to continue the processes and expenses already incurred for lithium-ion batteries. LIBs have been on the rise for many years, and many founders believe that by 2030 , these batteries could cost $\$ 50$ per $\mathrm{kWh}$ (up from $\$ 156$ today). For this aim, either the ASSB cell-manufacturing processes must be simple, time, and cost-efficient, or there must be the possibility to manufacture ASSB with the current LIB manufacturing lines.

Schnell et al., built a calculation model to compare manufacturing costs of complete ASSBs and compared them with conventional LIB manufacturing [73]. According to their calculations, the manufacturing costs for the sulfide-based ASSBs vary from 132 to $86 \$ \mathrm{kWh}^{-1}$, which is even higher than that of LIB with Si /C anode $\left(\sim 50 \$ \mathrm{~kg}^{-1}\right)$. However, the higher cell manufacturing costs are mainly due to the use of Li metal foil in their process. Considering the electrolyte part, even though the cost of SEs is higher than that of organic liquid electrolytes, cost savings are still possible due to the elimination of electrolyte filling and formation processes.

Many battery manufacturing companies claimed that they have been focusing on the development of SSBs based on InSEs. Very recently, a startup called Solid Power in Colorado introduced the first generation of ASSB pouch cells. The cells consisted of 10 layers and sulfide-based solid electrolytes. The company claims that the cells are delivering an energy density of $320 \mathrm{Wh} \mathrm{kg}^{-1}$, which is more than today's $18650 \mathrm{LIB}$ cells $\left(\sim 300 \mathrm{Wh} \mathrm{kg}^{-1}\right)$. In 2017, this company partnered with BMW AG in order to develop the next generation of battery technology for EVs [74]. 
Toyota has also announced that in 2025, they will be producing their first EVs running with ASSB together with Panasonic [74]. Toyota is accepted as the pioneer of ASSB research with more than 3000 patents in this field. The current solid-state electrolyte and solid-state battery manufacturers are depicted in Figure 2.
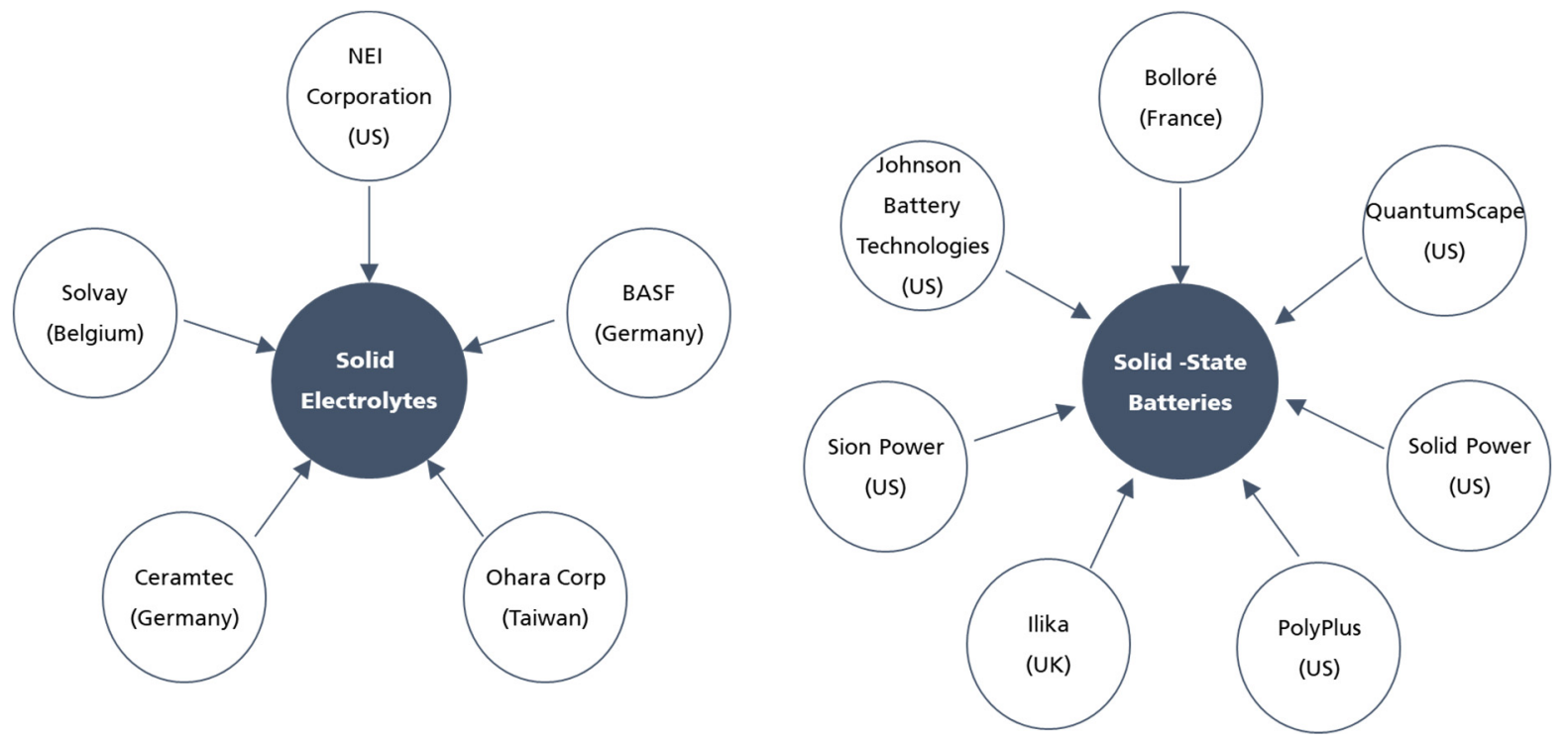

Figure 2. ASSB Market with key participants [74,75].

From a process technology point of view, there are different techniques for the fabrication of solid-state electrolytes. InSEs are mostly prepared by melt-quenching or mechanical milling methods [76,77]. However, SPEs present easier and low-cost process approaches such as hot pressing and extrusion processes [76]. The advantages and disadvantages of each technique are presented in Figure 3.

\section{Inorganic Sulfide Electrolytes}

MELT-QUENCHING

$\checkmark$ Solid-Phase Reaction

$\checkmark$ High conductivity

$X$ High temperature and energy requirement

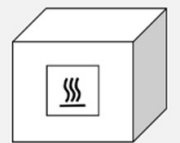

MECHANICAL MILLING

$\checkmark$ No additional pulverization process

$\checkmark$ Room temperature

$X$ Non-homogenous particle distrubution

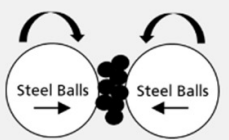

\section{Polymer Electrolytes}

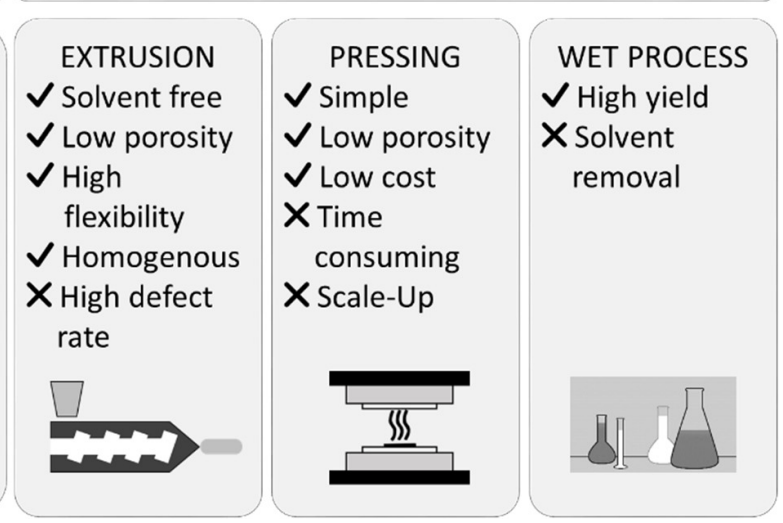

Figure 3. Most common preparation techniques of different type of SEs. Both inorganic solid electrolytes (InSEs) and SPEs can be introduced to SSB cell via cold- or hot- press techniques by pressing solid-state electrolyte powder directly to the cathodes. Nevertheless, there is a need for new approaches (e.g., use of binders) in order to increase cathode-solid electrolyte contact.

\section{Summary and Outlook}

Despite increased attention on all-solid-state batteries (AASBs), there are still challenges for achieving a rapid commercialization of this technology. Since the primary goal is to increase the energy density of today's LIB technology, the use of Li metal as an anode is indispensable in next-generation battery systems. As a result, research and development 
in the field of solid electrolytes are of primary importance not only for the electrochemical performances of the cell but also for the safety of the system.

Among different types of proposed solid electrolytes, solid sulfide electrolytes and SPEs are one-step ahead. According to the current state of research, only solid sulfide electrolytes allow the preparation of cells using current LIB cathode active materials with properties that correspond to or can exceed those of conventional LIBs. For this reason, all major industrial players are pursuing cell concepts based on sulfide electrolytes.

Solid polymer electrolytes offer more stability against Li metal, enhanced mechanical properties, and better processability. However, their oxidation sensitivity and lower ionic conductivities at room temperatures remain a challenge.

For achieving a successful cell, it is crucial to overcome (i) poor electrolyte-electrode contact, (ii) growth of lithium dendrites through the solid electrolyte, (iii) low ionic conductivity at room temperature (iv) high cost, and (v) the challenges related to the scalability of the related manufacturing processes.

In order to meet these challenges, hybrid solid electrolytes can be considered. The viable question here is "what type of hybrid"? Considering the huge importance of adapting SEs easily to conventional Li-Ion cell manufacturing, their ductility is of high importance. Typically, any Li-Ion manufacturing includes a densification step, the calendaring. If an $\mathrm{SE}$ is quite ductile, it can easily be cold-formed, and contacts between single grains can be greatly improved just by this step. This means, the conductivity of an optional bridging second solid (polymer) electrolyte between the grains of the main SE can be favorably lower, since the gaps become smaller after densification.

Consequently, much better electrical contacts can be achieved after the calendering step. These are huge advantages of sulfide-, phosphide-, and iodide-based solid Li-Ion conductors, as a result of their inherent ductile behavior. However, oxide-based solid Li-Ion conductors, tend to show a more ceramic behavior similar to $\mathrm{Al}_{2} \mathrm{O}_{3}$, such as in abrasive paper. Oxide-based solid Li-Ion conductors do not show any ductility and cannot be easily cold-formed. Thus, composites between them and a polymer electrolyte are much more unfavorable. This mechanical aspect is often neglected but is a clear vote for sulfide and phosphide-based candidates as solid Li-Ion electrolytes. This fact provides the third important reason as to why our focal point is on the sulfide (and phosphide) types of solid electrolytes and the polymers, but in this case as an appropriate bridging glue.

\section{Conclusions}

This paper provides strong reasons for sulfide/phosphide-based solid electrolytes vs. oxide/phosphate ones. Besides others, these have higher conductivity, feasible handling options for side reactions in production under ambient conditions, and mechanical properties such as ductility. Finally, it seems reasonable and feasible to combine sulfide/phosphidebased solid electrolytes with polymer electrolytes as a glue between the grains. This approach can yield excellent solutions for successful Li-dendrite suppression in highly compressed films as well as a simple and effective adaption of solid electrolytes to conventional Li-Ion manufacturing, particularly if this approach is combined with an in-situ Li metal anode formation upon the first charge in the formation step.

Author Contributions: D.K.: Conceptualization, Data curation, Investigation, Methodology, Visualization Writing—original draft, Writing—review \& editing; K.P.B.: Conceptualization, Data curation, lnvestigation, Methodology, Visualization Writing—original draft, Writing—review \& editing, Supervision; M.W.: Resources, review \& editing. All authors have read and agreed to the published version of the manuscript.

Funding: No Funding, internal research.

Institutional Review Board Statement: Not applicable.

Informed Consent Statement: Not applicable.

Data Availability Statement: Not applicable. 
Conflicts of Interest: The authors declare no conflict of interest.

\section{References}

1. Whittingham, M.S. Electrical energy storage and intercalation chemistry. Science 1976, 192, 1126-1127. [CrossRef] [PubMed]

2. Nishi, Y. Lithium ion secondary batteries; past 10 years and the future. J. Power Sources 2001, 100, 101-106. [CrossRef]

3. Xiang, H.; Zhang, K.; Ji, G.; Lee, J.Y.; Zou, C.; Chen, X.; Wu, J. Graphene/nanosized silicon composites for Lithium battery anodes with improved cycling stability. Carbon 2011, 49, 1787-1796. [CrossRef]

4. Chakrapani, V.; Rusli, F.; Filler, M.A.; Kohl, P.A. Silicon nanowire anode: Improved battery life with capacity-limited cycling. J. Power Sources 2012, 205, 433-438. [CrossRef]

5. Liu, B.; Zhang, J.-G.; Xu, W. Advancing Lithium Metal Batteries. Joule 2018, 2, 833-845. [CrossRef]

6. Wanga, L.; Zhoua, Z.; Yan, X.; Hou, F.; Wen, L.; Luo, W.; Liang, J.; Dou, S.X. Engineering of Lithium-metal anodes towards a safe and stable battery. Energy Storage Mater. 2018, 14, 22-48. [CrossRef]

7. Lau, J.; DeBlock, R.H.; Butts, D.M.; Ashby, D.S.; Choi, C.S.; Dunn, B.S. Sulfide Solid Electrolytes for Lithium Battery Applications. Adv. Energy Mater. 2018, 8, 1800933. [CrossRef]

8. TechVision Group. Innovations in Solid State Batteries: Need for Safer Alternatives Drives Innovations in Solid State Batteries; Frost \& Sullivan: Santa Clara, CA, USA, 2018.

9. Cao, C.; Li, Z.-B.; Wang, X.-L.; Zhao, X.-B.; Han, W.-Q. Recent Advances in Inorganic Solid Electrolytes for Lithium Batteries. Front. Energy Res. 2014, 2, 25. [CrossRef]

10. Aono, H.; Sugimoto, E.; Sadaoka, Y.; Imanaka, N.; Adachi, G.-Y. Ionic Conductivity of the Lithium Titanium Phosphate (Li $1+X$ $\mathrm{MX} \mathrm{Ti}{ }_{2}-\mathrm{X}(\mathrm{PO} 4) 3 \mathrm{M}=\mathrm{Al}$ Sc Y and La) Systems. J. Electrochem. Soc. 1989, 136, 590. [CrossRef]

11. Xia, W.; Xu, B.; Duan, H.; Guo, Y.; Kang, H.; Li, H.; Liu, H. Ionic Conductivity and Air Stability of $\mathrm{Al}_{-} \mathrm{Doped} \mathrm{Li}_{7} \mathrm{La}_{3} \mathrm{Zr}_{1} \mathrm{O}_{12}$ Sintered in Alumina and Pt Crucibles. ACS Appl. Mater. Interfaces 2016, 8, 5335-5342. [CrossRef]

12. Xia, S.; Wu, X.; Zhang, Z.; Cui, Y.; Liu, W. Practical Challenges and Future Perspectives of All-Solid-State Lithium-Metal Batteries. Chem 2019, 5, 753-785. [CrossRef]

13. Minafra, N.; Culver, S.P.; Li, C.; Senyshyn, A.; Zeier, W.G. Influence of the Lithium Substructure on the Diffusion Pathways and Transport Properties of the Thio-LISICON Li 4 Ge 1-x Sn x S 4. Chem. Mater. 2019, 31, 3794-3802. [CrossRef]

14. Rao, R.P.; Adams, S. Studies of Lithium argyrodite solid electrolytes for all-solid-state batteries. Phys. Status Solidi A 2011, 208, 1804-1807. [CrossRef]

15. Tatsumisago, M.; Nagao, M.; Hayashi, A. Recent development of sulfide solid electrolytes and interfacial modification for all-solid-state rechargeable Lithium batteries. J. Asian Ceram. Soc. 2013, 1, 17-25. [CrossRef]

16. Sakuda, A.; Hayashi, A.; Tatsumisago, M. Sulfide Solid Electrolyte with Favorable Mechanical Property for All-Solid-State Lithium Battery. Sci. Rep. 2013, 3, 1-5. [CrossRef]

17. Zhao, Q.; Stalin, S.; Zhao, C.-Z.; Archer, L.A. Designing solid-state electrolytes for safe, energy-dense batteries. Nat. Rev. Mater. 2020, 5, 229-252. [CrossRef]

18. Barai, P.; Higa, K.; Srinivasan, V. Lithium dendrite growth mechanisms in polymer electrolytes and prevention strategies Phys. Chem. Chem. Phys. 2017, 19, 20493-20505. [CrossRef] [PubMed]

19. Fergus, J.W. Ceramic and polymeric solid electrolytes for Lithium-ion batteries. J. Power Sources 2010, 195, 4554-4569. [CrossRef]

20. Lagadec, M.F.; Zahn, R.; Wood, V. Characterization and performance evaluation of Lithium-ion battery separators. Nat. Energy 2019, 4, 16-25. [CrossRef]

21. Kanno, R.; Murayama, M. Lithium Ionic Conductor Thio-LISICON: The Li 2 S-GeS $2-\mathrm{P} 2$ S 5 System. J. Electrochem. Soc. 2001, 148, A742. [CrossRef]

22. Kamaya, N.; Homma, K.; Yamakawa, Y.; Hirayama, M.; Kanno, R.; Yonemura, M.; Kamiyama, T.; Kato, Y.; Hama, S.; Kawamoto, K.; et al. A Lithium superionic conductor. Nat. Mater. 2011, 10, 682-686. [CrossRef] [PubMed]

23. Zhang, Q.; Hu, J.; Chu, Y.; Wan, W.; Zhao, L.; Zhu, Y. Electrochemical performance of sulfide solid electrolyte $\mathrm{Li}_{10} \mathrm{GeP}_{2} \mathrm{~S}_{12}$ synthesized by a new method. Mater. Lett. 2019, 248, 153-156. [CrossRef]

24. Zhang, Z.; Chen, S.; Yang, J.; Wang, J.; Yao, L.; Yao, X.; Cui, P.; Xu, X. Interface Re-Engineering of $\mathrm{Li}_{10} \mathrm{GeP}_{2} \mathrm{~S}_{12} \mathrm{Electrolyte}$ and Lithium anode for All-Solid-State Lithium Batteries with Ultralong Cycle Life. ACS Appl. Mater. Interfaces 2018, 10, $2556-2565$. [CrossRef]

25. Wenzel, S.; Randau, S.; Leichtweiß, T.; Weber, D.A.; Sann, J.; Zeier, W.G.; Janek, J. Direct Observation of the Interfacial Instability of the Fast Ionic Conductor $\mathrm{Li}_{10} \mathrm{GeP}_{2} \mathrm{~S}_{12}$ at the Lithium Metal Anode. Chem. Mater. 2016, 28, 2400-2407. [CrossRef]

26. Woo, J.H.; Trevey, J.E.; Cavanagh, A.S.; Choi, Y.S.; Kim, S.C.; George, S.M.; Oh, K.H.; Lee, S.H. Nanoscale Interface Modification of $\mathrm{LiCoO}_{2}$ by $\mathrm{Al}_{2} \mathrm{O}_{3}$ Atomic Layer Deposition for Solid-State Li Batteries. J. Electrochem. Soc. 2012, 159, A1120. [CrossRef]

27. Xie, D.; Chen, S.; Zhang, Z.; Ren, J.; Yao, L.; Wu, L.; Yao, X.; Xu, X. High ion conductive $\mathrm{Sb}_{2} \mathrm{O}_{5}$-doped $\beta$-Li $\mathrm{Li}_{3} \mathrm{PS}_{4}$ with excellent stability against Li for all-solid-state Lithium batteries. J. Power Sources 2018, 389, 140-147. [CrossRef]

28. Yao, X.; Liu, D.; Wang, C.; Long, P.; Peng, G.; Hu, Y.S.; Li, H.; Chen, L.; Xu, X. High-Energy All-Solid-State Lithium Batteries with Ultralong Cycle Life. Nano Lett. 2016, 16, 7148-7154. [CrossRef]

29. Zhang, Q.; Peng, G.; Mwizerwa, J.P.; Wan, H.; Cai, L.; Xu, X.; Yao, X. Nickel sulfide anchored carbon nanotubes for all-solid-state Lithium batteries with enhanced rate capability and cycling stability. J. Mater. Chem. A 2018, 6, 12098-12105. [CrossRef] 
30. Kato, Y.; Hori, S.; Saito, T.; Suzuki, K.; Hirayama, M.; Mitsui, A.; Yonemura, M.; Iba, H.; Kanno, R. High-power all-solid-state batteries using sulfide superionic conductors. Nat. Energy 2016, 1, 1-7. [CrossRef]

31. Kato, Y.; Hori, S.; Kanno, R. $\mathrm{Li}_{10} \mathrm{GeP}_{2} \mathrm{~S}_{12}$-Type Superionic Conductors: Synthesis, Structure, and Ionic Transportation. Adv. Energy Mater. 2020, 10. [CrossRef]

32. Ruiz, A.G.; Sola, P.C.; Palmerola, N.M. Advanced Material and Device Applications with Germanium: Germanium: Current and Novel Recovery Processes; InTech Open: London, UK, 2018.

33. Kato, Y.; Saito, R.; Sakano, M.; Mitsui, A.; Hirayama, M.; Kanno, R. Synthesis, structure and Lithium ionic conductivity of solid solutions of $\mathrm{Li}_{10}(\mathrm{Ge} 1-\mathrm{xMx}) \mathrm{P}_{2} \mathrm{~S}_{12}(\mathrm{M}=\mathrm{Si}, \mathrm{Sn})$. J. Power Sources 2014, 271, 60-64. [CrossRef]

34. Deiseroth, H.J.; Kong, S.T.; Eckert, H.; Vannahme, J.; Reiner, C.; Zaiß, T.; Schlosser, M. Li ${ }_{6}$ PS ${ }_{5}$ X: A Class of Crystalline Li-Rich Solids With an Unusually High Li+ Mobility. Angew. Chem. 2008, 120, 767-770. [CrossRef]

35. Hanghofer, I.; Brinek, M.; Eisbacher, S.L.; Bitschnau, B.; Volck, M.; Hennige, V.; Hanzu, I.; Rettenwander, D.; Wilkening, H.M.R. Substitutional disorder: Structure and ion dynamics of the argyrodites $\mathrm{Li}_{6} \mathrm{PS}_{5} \mathrm{Cl}, \mathrm{Li}_{6} \mathrm{PS}_{5} \mathrm{Br}$ and $\mathrm{Li}_{6} \mathrm{PS}_{5} \mathrm{I}$. Phys. Chem. Chem. Phys. 2019, 21, 8489-8507. [CrossRef]

36. Zhou, L.; Park, K.H.; Sun, X.; Lalère, F.; Adermann, T.; Hartmann, P.; Nazar, L.F. Solvent-engineered design of argyrodite Li ${ }_{6} \mathrm{PS}_{5} \mathrm{X}$ $(\mathrm{X}=\mathrm{Cl}, \mathrm{Br}, \mathrm{I})$ solid electrolytes with high ionic conductivity. ACS Energy Lett. 2018, 4, 265-270. [CrossRef]

37. Boulineau, S.; Courty, M.; Tarascon, J.; Viallet, V. Mechanochemical synthesis of Li-argyrodite $\mathrm{Li}_{6} \mathrm{PS}_{5} \mathrm{X}(\mathrm{X}=\mathrm{Cl}, \mathrm{Br}, \mathrm{I})$ as sulfur-based solid electrolytes for all solid state batteries application. Solid State Ion. 2012, 221, 1-5. [CrossRef]

38. Kasemchainan, J.; Zekoll, S.; Jolly, D.S.; Ning, Z.; Hartley, G.O.; Marrow, J.; Bruce, P.G. Critical stripping current leads to dendrite formation on plating in Lithium anode solid electrolyte cells. Nat. Mater 2019, 18, 1105-1111. [CrossRef]

39. Zhou, Y.; Doerrer, C.; Kasemchainan, J.; Bruce, P.G.; Pasta, M.; Hardwick, L.J. Observation of Interfacial Degradation of Li 6 PS ${ }_{5} \mathrm{Cl}$ against Lithium Metal and $\mathrm{LiCoO}_{2}$ via In Situ Electrochemical Raman Microscopy. Batter Supercaps 2020, 3, 647-652. [CrossRef]

40. Viallet, V.; Tarascon, J.-M.; Boulineau, S. Improvement of Electrochemical Performances of All-Solid-State Argyrodite-Based Lithium Batteries. In Proceedings of the 17th International Meeting on Lithium Batteries, Como, Italy, 10-14 June 2014 ; p. 757. [CrossRef]

41. Lee, Y.G.; Fujiki, S.; Jung, C.; Suzuki, N.; Yashiro, N.; Omoda, R.; Ko, D.S.; Shiratsuchi, T.; Sugimoto, T.; Ryu, S.; et al. High-energy long-cycling all-solid-state Lithium metal batteries enabled by silver-carbon composite anodes. Nat. Energy 2020, 5, 299-308. [CrossRef]

42. Wu, Z.; Xie, Z.; Yoshida, A.; Wang, Z.; Hao, X.; Abudula, A.; Guan, G. Utmost limits of various solid electrolytes in all-solid-state Lithium batteries: A critical review. Renew. Sustain. Energy Rev. 2019, 109, 367-385. [CrossRef]

43. Cheng, S.H.S.; He, K.Q.; Liu, Y.; Zha, J.W.; Kamruzzaman, M.; Ma, R.L.W.; Dang, Z.M.; Li, R.K.; Chung, C.Y. Electrochemical performance of all-solid-state Lithium batteries using inorganic Lithium garnets particulate reinforced $\mathrm{PEO} / \mathrm{LiClO}_{4}$ electrolyte. Electrochim. Acta 2017, 253, 430-438. [CrossRef]

44. Gorecki, W.; Jeannin, M.; Belorizky, E.; Roux, C.; Armand, M. Physical properties of solid polymer electrolyte PEO(LiTFSI) complexes. J. Phys. Condens. Matter 1995, 7, 6823. [CrossRef]

45. Rey, I.; Lassègues, J.C.; Grondin, J.; Servant, L. Infrared and Raman study of the PEO-LiTFSI polymer electrolyte. Electrochim. Acta 1998, 43, 1505-1510. [CrossRef]

46. Bouchet, R.; Lascaud, S.; Rosso, M. An EIS Study of the Anode Li/PEO-LiTFSI of a Li Polymer Battery. J. Electrochem. Soc. 2003, 150, A1385. [CrossRef]

47. Stolwijk, N.A.; Wiencierz, M.; Heddier, C.; Kösters, J. What can we learn from ionic conductivity measurements in polymer electrolytes? A case study on poly(ethylene oxide) (PEO)-NaI and PEO-LiTFSI. J. Phys. Chem. B 2012, 116, 3065-3074. [CrossRef] [PubMed]

48. Marzantowicz, M.; Dygas, J.R.; Krok, F. Impedance of interface between PEO:LiTFSI polymer electrolyte and blocking electrodes. Electrochim. Acta 2008, 53, 7417-7425. [CrossRef]

49. Molinari, N.; Mailoa, J.P.; Kozinsky, B. Effect of Salt Concentration on Ion Clustering and Transport in Polymer Solid Electrolytes: A Molecular Dynamics Study of PEO-LiTFSI. Chem. Mater. 2018, 30, 6298-6306. [CrossRef]

50. Utpalla, P.; Sharma, S.K.; Sudarshan, K.; Sahu, M.; Pujari, P.K. Investigation of the free volume characteristics of PEO based solid state polymer electrolyte by means of positron annihilation spectroscopy. Solid State Ion. 2019, 339, 114990. [CrossRef]

51. Wan, J.; Xie, J.; Kong, X.; Liu, Z.; Liu, K.; Shi, F.; Pei, A.; Chen, H.; Chen, W.; Chen, J. Ultrathin, flexible, solid polymer composite electrolyte enabled with aligned nanoporous host for Lithium batteries. Nat. Nanotechnol. 2019, 14, 705-711. [CrossRef]

52. Qiu, J.; Yang, L.; Sun, G.; Yu, X.; Li, H.; Chen, L. A stabilized PEO-based solid electrolyte via a facile interfacial engineering method for a high voltage solid-state Lithium metal battery. Chem. Commun. 2020, 56, 5633-5636. [CrossRef] [PubMed]

53. Wurster, V.; Engel, C.; Graebe, H.; Ferber, T.; Jaegermann, W.; Hausbrand, R. Characterization of the Interfaces in LiFePO $/ \mathrm{PEO}^{-}$ LiTFSI Composite Cathodes and to the Adjacent Layers. J. Electrochem. Soc. 2019, 166, A5410. [CrossRef]

54. Chen, H.; Adekoya, D.; Hencz, L.; Ma, J.; Chen, S.; Yan, C.; Zhao, H.; Cui, G.; Zhang, S. Stable Seamless Interfaces and Rapid Ionic Conductivity of $\mathrm{Ca}-\mathrm{CeO}_{2}$ / LiTFSI/PEO Composite Electrolyte for High—Rate and High—Voltage All—Solid—State Battery. Adv. Energy Mater. 2020, 10. [CrossRef]

55. Chen, R.J.; Zhang, Y.B.; Liu, T.; Xu, B.Q.; Lin, Y.H.; Nan, C.W.; Shen, Y. Addressing the Interface Issues in All-Solid-State Bulk-Type Lithium Ion Battery via an All-Composite Approach. ACS Appl. Mater. Interfaces 2017, 9, 9654-9661. [CrossRef] 
56. Porcarelli, L.; Aboudzadeh, M.A.; Rubatat, L.; Nair, J.R.; Shaplov, A.S.; Gerbaldi, C.; Mecerreyes, D. Single-ion triblock copolymer electrolytes based on poly(ethylene oxide) and methacrylic sulfonamide blocks for Lithium metal batteries. J. Power Sources 2017, 364, 191-199. [CrossRef]

57. Wakayama, H.; Yonekura, H.; Kawai, Y. Three-Dimensional Bicontinuous Nanocomposite from a Self-Assembled Block Copolymer for a High-Capacity All-Solid-State Lithium Battery Cathode. Chem. Mater. 2016, 28, 4453-4459. [CrossRef]

58. Hovington, P.; Lagacé, M.; Guerfi, A.; Bouchard, P.; Mauger, A.; Julien, C.M.; Armand, M.; Zaghib, K. New Lithium metal polymer

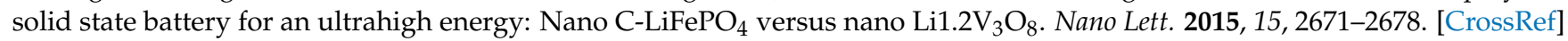
[PubMed]

59. Bouchet, R.; Maria, S.; Meziane, R.; Aboulaich, A.; Lienafa, L.; Bonnet, J.P.; Phan, T.N.; Bertin, D.; Gigmes, D.; Devaux, D.; et al. Single-ion BAB triblock copolymers as highly efficient electrolytes for Lithium-metal batteries. Nat. Mater. 2013, 12, $452-457$. [CrossRef] [PubMed]

60. Randau, S.; Weber, D.A.; Kötz, O.; Koerver, R.; Braun, P.; Weber, A.; Ivers-Tiffée, E.; Adermann, T.; Kulisch, J.; Zeier, W.G.; et al. Benchmarking the performance of all-solid-state Lithium batteries. Nat. Energy 2020, 5, 259-270. [CrossRef]

61. Homann, G.; Stolz, L.; Nair, J.; Laskovic, I.C.; Winter, M.; Kasnatscheew, J. Poly(Ethylene Oxide)-based Electrolyte for SolidState-Lithium-Batteries with High Voltage Positive Electrodes: Evaluating the Role of Electrolyte Oxidation in Rapid Cell Failure. Sci. Rep. 2020, 10, 1-9. [CrossRef]

62. Zhang, J.; Zhao, N.; Zhang, M.; Li, Y.; Chu, P.K.; Guo, X.; Di, Z.; Wang, X.; Li, H. Flexible and ion-conducting membrane electrolytes for solid-state Lithium batteries: Dispersion of garnet nanoparticles in insulating polyethylene oxide. Nano Energy 2016, 28, 447-454. [CrossRef]

63. Zhang, B.; Zhang, Y.; Zhang, N.; Liu, J.; Cong, L.; Liu, J.; Sun, L.; Mauger, A.; Julien, C.M.; Xie, H.; et al. Synthesis and interface stability of polystyrene-poly(ethylene glycol)-polystyrene triblock copolymer as solid-state electrolyte for Lithium-metal batteries. J. Power Sources 2019, 428, 93-104. [CrossRef]

64. Mauger, A.; Armand, M.; Julien, C.M.; Zaghib, K. Challenges and issues facing Lithium metal for solid-state rechargeable batteries. J. Power Sources 2017, 353, 333-342. [CrossRef]

65. Chen, R.; Li, Q.; Yu, X.; Chen, L.; Li, H. Approaching Practically Accessible Solid-State Batteries: Stability Issues Related to Solid Electrolytes and Interfaces. Chem. Rev. 2020, 120, 6820-6877. [CrossRef]

66. Wang, L.; Wu, Z.; Zou, J.; Gao, P.; Niu, X.; Li, H.; Chen, L. Li-free Cathode Materials for High Energy Density Lithium Batteries. Joule 2019, 3, 2086-2102. [CrossRef]

67. Takeda, Y.; Yamamoto, O.; Imanishi, N. Lithium Dendrite Formation on a Lithium Metal Anode from Liquid, Polymer and Solid Electrolytes. Electrochemistry 2016, 84, 210-218. [CrossRef]

68. Schmuch, R.; Wagner, R.; Hörpel, G.; Placke, T.; Winter, M. Performance and cost of materials for Lithium-based rechargeable automotive batteries. Nat. Energy 2018, 3, 267-278. [CrossRef]

69. Schnell, J.; Günther, T.; Knoche, T.; Vieider, C.; Köhler, L.; Just, A.; Keller, M.; Passerini, S.; Reinhart, G. All-solid-state Lithium-ion and Lithium metal batteries-Paving the way to large-scale production. J. Power Sources 2018, 382, 160-175. [CrossRef]

70. Zhang, T.; He, W.; Zhang, W.; Wang, T.; Li, P.; Sun, Z.; Yu, X. Designing composite solid-state electrolytes for high performance Lithium ion or Lithium metal batteries. Chem. Sci. 2020, 11, 8686-8707. [CrossRef]

71. Zhu, Y.; Mo, Y. Materials Design Principles for Air-Stable Lithium/Sodium Solid Electrolytes. Angew. Chem. Int. Ed. 2020, 59, 17472-17476. [CrossRef]

72. Bernhardt, W.; Gabaldon, D.; Zheng, R.; Schmitt, P.; Hotz, T.; Braun, S.; Kampker, A.; Offermanns, C.; Krämer, S. Rising Opportunities for Battery Equipment Manufacturers: Boom in Electric Cars and Li-Ion Batteries Shifts Manufacturing Equipment into Drive; Roland Berger GmbH: Munich, Germany, 2020.

73. Schnell, J.; Knörzer, H.; Imbsweiler, A.J.; Reinhart, G. Solid versus Liquid-A Bottom-Up Calculation Model to Analyze the Manufacturing Cost of Future High-Energy Batteries. Energy Technol. 2020, 8, 1901237. [CrossRef]

74. TechVision Analysis. Technological Advancements in Solid State Batteries for Electric Vehicles: Game-Changing Solid-state Batteries Will Push the Future Electric Vehicles to the Next Level. 2020. Available online: https://www.globenewswire. com/news-release/2021/01/27/2164871/0/en/Global-Solid-State-Batteries-for-Electric-Vehicles-Market-Report-2020-GameChanging-Solid-state-Batteries-Will-Push-the-Future-Electric-Vehicles-to-the-Next-Level.html (accessed on 1 December 2020).

75. Frost Perspectives. Solid-State Electrolytes-Next-Generation Safer Alternative in Li-Ion Batteries. 2017. Available online: https:/ / ww2.frost.com/frost-perspectives/solid-state-electrolytes-next-generation-safer-alternative-li-ion-batteries / (accessed on 1 December 2020).

76. Chen, A.; Qu, C.; Shi, Y.; Shi, F. Manufacturing Strategies for Solid Electrolyte in Batteries. Front. Energy Res. $2020,8,226$. [CrossRef]

77. Hayashi, A.; Sakuda, A.; Tatsumisago, M. Development of Sulfide Solid Electrolytes and Interface Formation Processes for Bulk-Type All-Solid-State Li and Na Batteries. Front. Energy Res. 2016, 4, 25. [CrossRef] 